\title{
An Integrated AHP-TOPSIS for Evaluating Online Marketing Strategies for the Hospitality Industry
}

\author{
Lanndon Ocampo, Cebu Technological University, Cebu, Philippines \\ (iD) https://orcid.org/0000-0002-5050-7606 \\ Orlyn Besabella, University of the Philippines, Cebu, Philippines \\ Marife Fallore, University of the Philippines, Cebu, Philippines \\ Adelfa Rose Guinandal, University of the Philippines, Cebu, Philippines \\ Angel Merabueno, University of the Philippines, Cebu, Philippines \\ Celbert Himang, Cebu Technological University, Cebu, Philippines \\ iD https://orcid.org/0000-0002-5663-3304 \\ Kafferine Yamagishi, Cebu Technological University, Cebu, Philippines \\ iD https://orcid.org/0000-0002-0775-6156
}

\begin{abstract}
Online marketing has been the most efficient and useful platform for reaching target markets and building customer relations. Despite its widespread use, the hospitality industry is at its forefront of identifying its most suitable online marketing strategies. This emphasis is crucial to strategic marketing and resource allocation decisions, which may impact the long-term performance of businesses. The need to address both perspectives of customers and businesses, along with the multiple online marketing strategies under the presence of multiple criteria, requires a rigorous analytical and comprehensive approach for evaluating the efficacy of these strategies for the hospitality industry. Thus, this work offers an integrated approach based on the analytic hierarchy process (AHP) and the technique for order of preference by similarity to ideal solution (TOPSIS) as a decision-making platform for the problem domain. The AHP assigns the corresponding priority weights of the criteria associated with either customers' or businesses' perspectives, while the TOPSIS ranks the importance of the strategies. Results show that the credibility of an online marketing strategy is of the highest priority for the customers, while the businesses highly regard customer loyalty. With the AHP-TOPSIS approach, findings reveal that both perspectives prefer search engines for the hospitality industry. Illustrating the results via a priority tradeoff map of two perspectives, search engines, websites, and blogs are deemed the most viable online marketing strategies relevant to the industry. These findings offer dependable guidelines for the hospitality industry in positioning their online marketing efforts.
\end{abstract}

\section{KEYWORDS}

Analytic Hierarchy Process, Hospitality Industry, Online Marketing Strategies, TOPSIS 


\section{INTRODUCTION}

In Asian countries, the service industry contributes $60 \%$ or more of their GDP (Park \& Shin, 2012). In the Philippines, the service industry contributed $52.9 \%$ to its 2004 GDP (Mitra, 2013). The growth was steady, with a GDP share of 56.7\% in 2014 and 58.8\% in 2015 (Asia Pacific Economic Cooperation, 2015). One important component of the service industry is the hospitality sector. Meanwhile, the increasing use of the Internet promotes the dramatic growth of online marketing. Companies are now using the Internet to reach their target market (Smith, 2011). For instance, in the hospitality industry, online reservation systems (Guo et al., 2013; Ozturk et al., 2016) and websites (Gan et al., 2007) have become increasingly dominant. Those that have online leads are growing more than those without online leads. Also, they are generating up to $45 \%$ of profits compared to those with zero online leads (McGlaughlin et al., 2012), making today the most dynamic period in marketing history (Valos et al., 2010). The growing awareness of the potential leverage when implementing online marketing is now seen, as the service industry is putting in more resources to it as the industry sees it tantamount to increasing company's brand awareness and sales (Mustafi et al., 2011).

Numerous online marketing strategies are prevalent in the service industry. The most popular platform is social media. Lorenzo-Romero et al. (2014) pointed out that social media allows marketers to directly market their product and reach their target audience while at the same time serving as a public relations channel of the company. A study by the University of San Francisco highlighted that $72 \%$ of U.S. adults who are online use Facebook. This implies that Facebook is the primary destination among other online networking sites. Another online strategy that dominates companies is online content marketing. Unlike social media, content marketing can be present in any online platform as its primary is focused on the quality of the content that the companies would communicate to drive profitable customer action (Ahmad et al., 2015). Video marketing, on the other hand, is considered a pillar in content marketing. In video marketing, marketers can make use of text, graphics, or videos to be more effective in their strategies.

Due to the potential leverage companies could take, an increasing number of businesses nowadays are engaging in online marketing in doing business. One of the striking advantages is a low-cost advertisement online marketing incurs compared to the traditional ones. For example, they can get a free listing in many online business directories. They could connect to customers more than they usually would, and contact is more affordable than methods, such as sending mail, printing brochures, and paying for postal costs. Another advantage that businesses acquire when implementing online marketing is the ability to track the results of advertising efforts, with insightful analytics and visualizations, which would provide traffic growth, leads, and sales conversions (Linton, 2016). With the use of online marketing strategies, distance is no longer an issue. It is possible to sell and advertise anywhere with the presence of the Internet. Such ability enables businesses for global reach. Also, a significant portion of the population now relies on social media as a reference point before product or service purchase (Kim \& Ko, 2012). The most important advantage of online marketing is its ability to connect and build relationships with customers. The Internet provides an essential platform for building relationships with customers and increasing customer retention levels.

Given the advantages of implementing online marketing in the hospitality industry, it is reasonably beneficial for hospitality businesses to position their marketing initiatives along with it. Understanding resource allocation decisions in business operations, identifying which online marketing strategy to invest in ensures value and presence in the market, building visibility, and generating sales. Thus, such a process of identifying the most appropriate strategy is crucial for setting the direction of hospitality businesses into online marketing. For obvious reasons, this initiative must reach the target market and build customer relations (Kirca et al., 2005; Wuyts et al., 2015). However, businesses also have their inclinations, which must be addressed (Murillo \& Martinek, 2009). Thus, these two streams of interest provide a holistic view on crafting an online marketing strategy for the hospitality industry. With these interests coupled with the evaluation of multiple alternatives in the presence of a number 
of criteria, the decision-making process becomes complex. The online marketing strategy selection must be treated as a multi-criteria decision-making (MCDM) problem in addressing such evaluation. The set of tools for MCDM problems provides an essential mechanism in analyzing such problems of evaluating different alternatives under multiple criteria (Velasquez \& Hester, 2013). Despite the presence of MCDM tools along with the importance of the problem domain, current literature fails to bridge this gap.

Thus, this work advances this gap in current literature by proposing an approach for the hospitality industry in selecting an online marketing strategy considering both the customers' and businesses' perspectives. In carrying out this objective, an integrated approach based on the analytic hierarchy process (AHP) and Technique for Order of Preference by Similarity to Ideal Solution (TOPSIS) is proposed in this work. Saaty (1980) developed the AHP as a priority measurement tool in dealing with MCDM problems where decision elements are structured in a hierarchy, and judgment elicitations are based on pairwise comparisons of these elements. Among all MCDM methods, AHP is flexible, intuitive, and has the control mechanism for judgment inconsistencies (Velasquez \& Hester, 2013). The strength of the AHP is its capability to break down complex, unstructured problems into levels of a hierarchy. The most recent review of the AHP and its applications is reported by Ho and Ma (2018). Developed by Hwang and Yoon (1981), the TOPSIS is based on the concept that the chosen alternative should have the shortest geometric distance from the positive ideal solution and the longest geometric distance from the negative ideal solution. Its main advantage lies in its simplicity and ability to maintain the same number of steps regardless of the size of the problem, aside from its increased computational tractability (Velasquez \& Hester, 2013). Yadav et al. (2018) discussed the most recent review of the applications of the TOPSIS method. In work, the AHP provides the priority weights of the criteria, while TOPSIS ranks the importance of the online marketing strategies for the hospitality industry. Such an integration augments the capability of the TOPSIS method in providing a systematic approach in coming up with priority scores of the criteria, a step that was not offered in the original TOPSIS formulation. A case study in the hospitality industry in the Philippines was adopted to demonstrate the proposed approach. The contribution of this study is the development of a flexible online marketing strategy selection decision for the hospitality industry that integrates both customer and business needs.

This paper is organized as follows: Section 2 discusses the review of the domain literature of online marketing, hospitality industry, and the two crucial perspectives in dealing with online marketing. Section 3 details the methodology and the required computational steps in the strategy selection problem. The findings and insights of the results are provided in Section 4. It ends with a conclusion and a presentation of future works in Section 5.

\section{LITERATURE REVIEW}

\subsection{Online Marketing}

In a straightforward sense, online marketing, also known as internet marketing or web marketing, is marketing with technology and the Internet. It has evolved over the years and became an apparent necessity for almost all businesses across different industries. Online marketing becomes the fastest growing and most exciting mode of marketing today. The leverage lies in using information technology in traditional marketing in delivering value to global customers as the Internet hosts a global network of interconnected networks (Tamilarasan, 2014). Online marketing provides businesses greater flexibility and innovation to reach customers and deliver customer value. It allows them to position their 4Ps (i.e., Product, Price, Place, and Promotion) in ways attractive to the market. The organization's online marketing programs become more efficient in their operations and may potentially increase network connections. It has become a prominent choice of organizations in their marketing functions because of its low cost, low maintenance, and effectiveness in drawing people (McKee, 2016). It altogether becomes vital to explore how the Internet as a marketing platform can be exploited to market goods 
and services that could result in reinventing the marketing wheel to evolve strategies that best serve the needs of the e-marketing world (Tamilarasan, 2014).

\subsection{The Different Online Marketing Strategies}

Various online marketing strategies are widely used by service industries at present. We define these strategies as popular online platforms where most businesses market their services and connect to their customers.

\subsubsection{Social Media}

In the context of service branding, social media are designed and engineered to facilitate the dissemination of content and interaction between individuals, groups, and organizations using webbased technologies. Social media provides a set of distinct and complementary online channels for building and maintaining customer relationships that influence customer perceptions of their relationship with service brands, brand trust, risk, and service quality, outside of its offline marketing support function (Mills \& Plangger, 2015).

The following are the types of social media.

\subsubsection{Microblogs}

Microblogs are social networking services that enable users to post and read concise messages, restricted by the number of characters in the message and the type of content that can be posted. Essentially, these are scaled and stripped-down versions of traditional blogs (Mills \& Plangger, 2015). One popular microblogging platform nowadays is Twitter that can send short messages known as tweets. The message would be posted on the author's profile page and seen by his or her followers.

Business sectors, particularly those in the service industries, are now also using micro-blogs to update their target market or consumers about their latest news or redirect links from their websites. An example of a service company that uses Twitter is Globe, a telecommunication service company in the Philippines, which uses the platform to address complaints and answer questions. The downside of this platform is its character limits and short-lived exposure online because new updates would bury old tweets in a profile's timeline (Yang \& Wang, 2015). In other places such as Europe, microblogs are also widely used especially in the destination marketing organization industry (Slivar \& Križman Pavlović, 2012).

\subsubsection{Video Sharing Sites}

The most popular video-sharing website today is YouTube. Anyone can see videos, but only registered members could post and comment about the video. Different industries are now exploiting this service in establishing customer relationships and promotions, which set the intensive competition in the said platform. Hotels and restaurants can benefit from this platform by showing videos of their place and offerings as a form of marketing and advertising at the same time. Considering the number of related videos available online, a video must be creative and unique enough to be worth the viewer's attention. With the free posting platform, marketers may receive low and unforgiving comments that might never be removed and cause a bad reputation and image.

\subsubsection{Picture Sharing Sites}

Picture sharing websites operate in much the same way as video sharing websites but with content based on still images instead of videos. The most popular picture sharing websites are Instagram, Flickr, Picasa, Pinterest, and Google Images. Launched in late 2010 exclusively for smartphone operating systems, Instagram reached 75 million users by 2014, posting upwards of 16 billion photos (Karimkhani et al., 2014). Latiff and Safiee (2015) pointed out that Instagram attracts many famous people to set up their accounts, which becomes an advantage to these business sellers. With Instagram, for instance, these sellers could establish a personal relationship with their customers at a lower cost. 
One of the challenges of using Instagram is the sense of exclusivity (Latiff \& Safiee, 2015). They emphasized that due to the vast competition happening on Instagram, the business should have a unique selling proposition to create a hype of products and set them apart from competitors. Since Instagram limits the experience of customers on sight and hearing only, it is a challenge for a business to create a unique way of marketing their products. Another challenge of using Instagram is the handling of negative reviews (Latiff \& Safiee, 2015). Vigilance is required in case negative reviews and comments appear on the site. Handling these reviews and comments should be done carefully as it is quite transparent how the brand owners speak with the customers, which is a reflection of the brand. Another picture sharing platform is Pinterest. On Pinterest, users can view photos of different people and could "pin" them to retain that photo on their profile. These platforms allow service industries to communicate with their customers regarding their offerings and launch promotions using attractive visuals. Being updated and having constant interaction with customers allow effective marketing in this industry.

\subsubsection{Social Networking Sites}

Mills and Plangger (2015) described social networking websites as channels on which users can create an individual profile page, find and add friends and contacts, send messages and update their profiles to notify friends and contacts or colleagues about themselves. One of the famous social networking sites today is Facebook, which is founded in 2004. Many individuals are now joining Facebook because users could express their thoughts and opinions through their accounts and posts. With this capability, service companies find it an opportunity to create business and company pages on social networking platforms. Possible reasons for the existence of these business profiles and pages are to promote and market and, at the same time, connect with its target market. However, having the freedom to express on Facebook enables bad-mouthing instances that could imply a risk to business users, such as bad publicity, given the extensive reach of the platform.

\subsubsection{Website}

The growth of the Internet and its increasing number of users have brought the popularity of company websites (Benslimane \& Yang, 2007). Websites nowadays are customer-oriented and informationintensive (Li et al., 2015) digital portal of companies. Lee and Kozar (2012) pointed out that websites provide a positive attitude in a company's online stores, increase the revisit rates, and eventually result in online purchases. Also, successful websites integrate their business functions in the information found on the site, communicate, transact, and build relationships with their customers (Li et al., 2015). One opportunity in creating a website is that adults are now a growing segment of internet users. Wagner et al. (2014) highlighted that as the Internet becomes part of people's lives, many are now using the Internet in their daily jobs. Such an opportunity increases the company website's reach. A company's website is also considered a "front-line" platform that disseminates information and decreases its operating cost while increasing its competitive advantage (Hung et al., 2014).

However, aside from the advantages brought by websites, there are few challenges that websites face. Lee and Kozar (2012) revealed that even with the knowledge of the importance of websites, several websites still contain usability problems. As companies are trying to adapt to technological changes, some forgot that customers would prefer a simple, easy, and user-friendly website rather than a complex one (Belanche et al., 2012). However, websites differ depending on their functionalities. Benslimane \& Yang (2007) revealed that complex websites are transactional websites that support the entire process of purchasing online, while more accessible and user-friendly websites are informational websites that support the identification of the company's products. Nonetheless, transactional websites incur more costs than informational websites. Also, Hung et al. (2014) pointed out that companies would need technological and human resources for website implementation. Lastly, in creating a website, companies must be wary of the language and cultural differences, especially if they are going global (Lituchy \& Barra, 2008). A neutral website that adjusts to different cultures may be a 
need (Singh \& Matsuo, 2004). However, this might limit a company because one thing might mean something different in another culture.

\subsubsection{Blogs}

Blogs are frequently updated web-based communication platforms that consist of texts, pictures, sound files, and other multimedia posted regularly by individuals (Schmidt, 2007). It is an online marketing strategy that makes use of the consumer-to-consumer approach instead of the usual business-toconsumer. In this platform, customers are exposed to various media where they can access different information regarding the product. This information, however, is not written by the service provider or any individual related to the business. Instead, they are written by consumers who have directly experienced the services (or products) rendered by a company (Li \& Du, 2011). These individuals are referred to as opinion leaders since they can influence their readers' decision-making process and even their purchasing behavior (Venkatraman, 1989).

Despite being a relatively new platform for online marketing, blogging activity has recently gained popularity ( $\mathrm{Li} \& \mathrm{Du}, 2011$ ). For one, an online social blog provides an effective channel for electronic word of mouth (e-WOM). In the case of the service industry, such as the hospitality industry, it is deemed favorable for the company if customers will have positive feedback about their service. Nowadays, people are increasingly emphasizing the value for money of the product or service they purchase. In addition, since the opinion leader or the "reviewer" performing the review is not affiliated with the business, customers develop trust and confidence that what the opinion leader is saying must be unbiased. As pointed out by $\mathrm{Li}$ and $\mathrm{Du}$ (2011), online social blogs have higher credibility than other types of online marketing because there is no apparent connection between the business owner and the person doing the review. However, because businesses do not have direct control over the person who performs the blogging and reviewing, blogs can potentially jeopardize the operation of the business. Due to an opinion-driven environment, customers would inevitably have negative blogs and reviews about a service. Thus, businesses in the service industry must monitor reviews made by their customers in order to defend themselves on whatever issues that were brought forward. Although negative e-WOM can be harmful to the business, Subramani and Rajagopalan (2003) pointed out that it is also essential to take note of the presence of negative e-WOM as it highlights the gap between what the company promises and what the customers actually experience. Businesses must make use of these comments to improve their services and to address what customers want to avoid future conflict or dissatisfaction.

Another advantage of using blogs as online marketing platforms is that blogs are cost-efficient (Kotler, 2003). Unlike other online marketing strategies, such as a website where maintenance and updates are necessary, companies do not have to pay individuals for their blogs. Generally, individuals who are into blogging activities speak directly from their experience with no fees in exchange. Though some literature would indicate that WOM is manipulated by marketers already, people still consider recommendations and information coming from consumers (Pan et al., 2007). Also, blogs allow direct interaction with their customers. This characteristic of a blog is considered as its major strength (Gardner, 2005). With this, businesses can directly solicit feedback from their customers. Halvorsen et al. (2013) set a similar position by espousing that blogs are indeed one of the cheapest strategies companies can use. Yet, the issue of coherence of the subject matter over time outweighs the monetary value of maintaining the blog. There is no assurance for the company whether a contradiction in the statement would exist, and if it does, it would cause distrust among its customers. In the service industry (e.g., hotels), where most of its strategy is integrated into online platforms, trust is crucial to make a sale. In effect, instead of being a cheap strategy, blogs can become an expensive liability for the company. Furthermore, Kaplan and Haenlein (2011) argued that blogging is yet to prove its value in return on investment, whether it would yield a positive return on investment or not. 


\subsubsection{Email Marketing}

Email is used as a primary tool for business communication and collaboration (Stuit \& Wortmann, 2012). McCloskey (2006) found that email marketing is growing with a $10 \%$ annual rate. With the increasing usage of the Internet, Mano and Mesch (2010) argued that electronic communication became increasingly crucial in getting access to vast quantities and high-quality information. As interactions through emails occur in both people's personal and professional lives (Stuit \& Wortmann, 2012), this inexpensive communication channel provides people an efficient way of sharing information and knowledge (Figallo \& Rhine, 2002). Consider the tobacco industry as a case in point. Brock et al. (2016) explained that the tobacco industry uses email marketing because tobacco companies can reach both consumers and comply with regulations. Also, using email marketing allows businesses to avoid negative public perception. Email marketing is used in promoting contests, including information about the company and coupons offered by the company (Brock et al., 2016). However, this scheme is not only attributed to tobacco companies. Email marketing of other industries includes the promotion of a contest and sweepstakes. This shows how email marketing plays a significant part in relationship marketing with consumers. Ellis-Chadwick and Doherty (2012) highlighted that email marketing is now an essential medium that companies need to take advantage of, especially if they aim to have and maintain a closer relationship with their consumers. Another equally important motivation for the widespread use of emails nowadays is its low setup and distribution costs (Moustakas et al., 2006). For the company, it promotes efficient distribution of promotional messages; for consumers, it helps them receive materials that match their interests (Grunert, 1996).

However, despite the advantages of email marketing, companies face a challenge with customer ease in discarding and deleting the messages and never seeing them again (Ducheneaut $\&$ Watts, 2005; Ellis-Chadwick \& Doherty, 2012). Also, Pavlov et al. (2008) pointed out that email marketing is faced with the danger of being bombarded with unwanted commercial emails. Spam emails account for 88\% of email traffic in August 2007 (Garretson, 2007). Some may find these messages interesting, but as many commercial and promotional emails are received, information overload becomes evident. It may result in a bad customer experience. Nevertheless, as in any strategy, the efficacy of email marketing is matched by its negative consequences (Pavlov et al., 2008), and companies must strike a good balance of these issues.

\subsubsection{Commerce Community}

The widespread use of social media and social network service allows users to interact and create online communities. These communities are usually grouped according to shared interests among members. When these people engage in transactions involving money, they are now in a commerce community. The commerce community platform allows buyers and sellers to communicate and share information about a product or a service. In its definition, e-commerce is the electronic process by which individuals or organizations make a transaction, such as buying, selling, transferring, or exchanging products, services, and information (Turban et al. 2004). For startup businesses, this mechanism becomes an excellent opportunity in the sense that they do not need to have significant investments at the start of their operations. If the people running the business are still testing the market, the use of this strategy may be more relevant to determine the responsiveness of its prospective customers. Jelonek and Stepniak (2014) enumerated some four advantages of employing this strategy: availability, a wide range of assortment, access to an unlimited amount of information, and the form of payment where customers have the option based on their most preferred and convenient form. Apparently, one potential cause of concern of commerce communities is the perceived trust among buyers. Bredzel-Skowera and Turek (2015) noted that the safety of online shopping is the worst rated.

\subsubsection{Online News}

Unlike traditional news, where most of the inputs come from journalists, the presence of online news allows users to contribute additional information and write opinion comments on issues that may be 
relevant to them. It encourages user-generated content as well as user-to-user interaction (Liu et al., 2015). Like blogs and other content marketing, this platform facilitates the exchange of information from one user to another. The advantage of this is that readers of online news would not be limited to the information given by journalists alone. If people have their own opinion regarding a matter of interest, they can write it down in the comment section. However, features of online news are limited and incomplete (Liu et al., 2015). For instance, distinguishing credible and quality online information from what is not has dramatically concerned the readers (Go et al., 2016).

\subsubsection{Search Engines}

Spais (2010) described a search engine as an approach in online marketing that allows certain company websites to be at the top when a keyword is searched. Its objective is to increase the number of web visitors to a page using appropriate keyword strings. As one of the famous types of search engine marketing, search engines are not entirely used in increasing web site's ranking but also in leading web domination (Olbrich \& Schultz, 2008; Thelwall, 2001). In achieving a higher ranking, search engines provide a variety of techniques; it includes increasing links from other websites to company web pages, editing the content of the website, reorganizing the structure and organization of the company website, and coding changes (Shih et al., 2013). At present, there are many popular search engines in use include Google, Bing, Yahoo, MSN, AOL, ASK, among others. Currently, Google is the most widely used search engine at 83\% (Netmarketshare, 2013). McGuigan et al. (2013) reported that currently, $85 \%$ of consumers use search engines to find information whenever they plan to buy certain products.

Nazar (2009) stipulated that the primary advantage of search engines is a company that can be ranked in the top ten without any hassle, and people prefer clicking the first result they see. He also mentioned that the higher the website rank is, the easier it is to find increasing traffic. Also, search engines are an excellent long-term investment in brand awareness once a successful strategy is put forward. However, Berman and Katona (2013) found out that although search engines can improve consumer welfare and the payoff of high-quality sites, the revenues gained from search engines are typically lower when advertisers spend more on search engines and thus less on sponsored links. In addition, no assurance is guaranteed that all visitors to the page would avail of the product or service.

\subsubsection{Pay-Per-Click}

The nature of pay-per-click as an advertising tool lies in the company paying the administrator of the site running the program for each user who clicks the ads. The leverage of this platform is that the company is assured that individuals clicking through the ads would be redirected to a business site. However, on a downside, the disadvantage of using this platform is that the programs are susceptible to hit inflation, where a referrer artificially inflates the click-through count for which it should be paid (Anupam et al., 2000). One of the most popular pay-per-click in the Philippines is Nuffnang, which is widely seen mostly in blogging platforms. Pay-per-click can be found even in personal blogging sites such as Tumblr and Blogspot such that writers and bloggers allow banner ads to be in their pages to earn whenever a reader clicks a banner.

\subsection{The Hospitality Industry}

The Internet brought drastic changes worldwide, disrupting various industries. Due to its increased use, enterprises are now taking the leverage of this new platform. For service industries, one major problem that businesses are facing is underutilized services. For instance, in the hotel industry, the possibility of having unbooked rooms is almost inevitable. In this case, unbooked rooms could be compensated by high demands in another season. Ladany (1996) pointed out that a proper pricing strategy could help hotel industries fully utilize their high margin and zero-salvage products. Basic pricing strategy adopted by hotels are: (1) for consumers who reserve rooms on the target day or one or two days earlier pays a higher rate, (2) consumers who reserve rooms a long time before the 
target day pays medium rate, and (3) consumers who book rooms more than two weeks earlier before the target day pays a lower rate. In e-tourism, the prevalent platform in use is an online reservation system (ORS), where e-consumers reserve hotel rooms anywhere and anytime given that they have access to the Internet (Guo et al., 2013). The ORS of a hotel is often visible on their websites. Abrate et al. (2012) studied some hotels in Singapore that use the ORS, namely, Marriott International Inc., Hilton Hotels, and Hotel ICON. The three hotels have a different approach to using their ORS. Marriot International, Inc. and Hilton Hotel offer a 25-50\% discount to their consumers when they book rooms 30 days earlier via the Internet. For the Hotel ICON, however, they offer a $20 \%$ fixed discount to their consumers when they book rooms at least 14 days earlier. Hotels use their strategies as to what they think fits with their current status and revenue goals. These strategies are a win-win policy for both the consumers and service providers (Guo et al., 2013). Hotels may fully utilize their service capacity, and consumers would be provided with price discounts.

However, though the online reservation system is a win-win policy for both consumers and hotels, Rus and Negrusa (2014) found out that $22.8 \%$ of hotels in Romania do not have their website, and only $12.8 \%$ of hotels use online booking systems. This shows how hotels are unsure if such investment could bring in increased sales. Also, this serves as a challenge due to the limited knowledge of the effectiveness of the ORS. Another challenge that may significantly affect online hotel bookings is user reviews. Ye et al. (2011) confirmed that online WOM significantly impacts online hotel bookings. This observation demonstrates that negative reviews from users can affect the user perception of a hotel ORS. Ozturk et al. (2016) emphasized that mobile hotel booking gives consumers an entertaining and enjoyable booking experience that allows them to complete their booking anytime and anywhere. However, if hotels have many distribution channels, they may need to manually update their booking or cancellations in the ORS, both timely and costly (Rus \& Negrusa, 2014).

Another way on how the hospitality industry may take advantage of the Internet is by strengthening its websites. Such an initiative maximizes relationship marketing. Gan et al. (2008) defined relationship marketing as a strategy where an organization emphasizes retaining its current consumers and improving its business relations by developing product relationships. Rosenberg and Czepiel (1984) once claimed that it is much costly to attract new consumers rather than retain current ones, emphasizing the need of hotel industries to embrace relationship marketing. In the case of Singapore hotel websites, Gan et al. (2007) identified four relationship marketing levels. The first is the information provision level, where they put minimum web features for necessary communication to their consumers. Second is the database collection level, where they present more in-depth hotel information for the customers. They also collect consumer databases and identifies consumer preferences. The third is the personalization level, where they personalize their websites to form a closer relationship with their consumers by adding value-creating features such as member sign-in option and cancellation tool. Lastly is the community relationship level, where they create cyber-community building. At this level, they aim to create a service, not just a website, that would result in a long-term relationship with their consumers. Gan et al. (2007) emphasized that considering customer needs and preferences is essential to ensure that the investments on their websites pay off.

Websites support relationship marketing as it serves as an interactive, many-to-many marketing tool ( $\mathrm{Li}$ et al. 2015). Websites provide direct contact between organizations and consumers, which offers convenience for the hotel's consumers. The use of their website became their leading platform in maintaining their customers. With that, websites could transform the static and passive relationship into a dynamic and interactive one (Escobar-Rodríguez \& Carvajal-Trujillo, 2013). Early website adopters create websites as they became a trend for hotels; however, there exist gaps in understanding the benefits and objectives of developing websites. In contrast to the early adopters, Ismail et al. (2009) found out that those younger hotels that adopted websites showed more effective website implementation than their earlier counterparts. Also, other challenges confront hotel websites. Li et al. (2015) argued that though most hotels know the importance of building relationships with their consumers, many still focus on developing applications while only a few concentrate on building 
long-term relationships. Another challenge for hotel websites nowadays is creating more advanced website features while focusing on relationship-oriented features. One emerging concern relevant in this undertaking is the identity of target customers. Escobar-Rodríguez and Carvajal-Trujillo (2013) observed a distinction between information-oriented towards customers and information-oriented towards investors. Bigger hotel chains tend to focus on their investors, while smaller hotels focus more on their customers. This shows how hotels of different sizes vary in terms of their website approach.

\subsection{The Two Relevant Perspectives: Customers and Businesses}

In selecting a specific online marketing strategy, the customers' consideration would be the top priority. However, businesses also have their own set of needs, which must also be addressed. Thus, these two streams of interests provide a holistic view on crafting an online marketing strategy for any industry, particularly relevant to the hospitality industry. Current literature suggests that firms with a strong customer focus stimulate high customer satisfaction (Kirca et al., 2005) and have firmly held institutionalized processes directed toward understanding and addressing their needs (Wuyts et al., 2015). Recent years have increased emphasis on customer-focused marketing approaches (Ambler et al., 2002). Gretzel et al. (2000) asserted that one of the success factors for marketing on the Web includes engaging users' interest and participation through customized interactions. To successfully deal with customers, several studies reveal that online marketing websites focused more on customer needs. For instance, Reichheld and Schefter (2000) described the essential qualities of a website to allow customer retention, and some of these are compelling product presentations and a transparent and trustworthy privacy policy. Nonetheless, for online marketing, customers also look into the dependability (Zeithaml, 2002), convenience (Han \& Mills, 2006), responsiveness (Lee \& Kozar, 2006), and credibility (Jun et al., 2004) of specific strategies companies are engaging with. Dependability refers to the technical functioning of the website (Zeithaml, 2002), which includes accessibility, speed, and ability to download information (Madu \& Madu, 2002) quickly. Convenience refers to how easy it is for users to access the information they want on the websites and the ease of passing through the sub-pages, including standard menu structure, search engines for website contents, and directories indication of user position in the menu structure. Responsiveness deals with providing information on Frequently Asked Questions (FAQs), giving feedback to the user for the transactions and results, and prompts assistance for solving problems (Ahn et al., 2007; Akincilar \& Dagdeviren, 2014; Ho \& Lee, 2007). Lee and Kozar (2006) added that e-service providers could implement various service functions on the website, such as complaint management systems, to provide superior service to its customers.

While customers have their own set of needs, businesses, on the other hand, also have varying needs, which may be different from the customer needs. Maximizing profits for its owners and stakeholders is deemed the primary goal of any business (Hernández-Murillo \& Martinek, 2009). In carrying out this goal, several needs of businesses require utmost attention. On this note, the online marketing concepts that should be taken into account from a business perspective include cost, reach, customer loyalty, and convenience. Cost refers to the monetary value involved in acquiring, developing, and implementing online marketing strategies. For highly obvious reasons, businesses prefer lower costs. Reach refers to the quantitative measure of business communication towards customers. It denotes the number of users reached by the firm through online marketing regardless of their feedbacks and insights. Technically, higher coverage is more favorable, as a broader scope of customers is reached. Meanwhile, customer-loyalty refers to the relationship built by the business to its customers. It refers to a relationship that allows customers to trust and stay with the business. Convenience denotes the ease of designing and maintain an online marketing strategy. Slater (2014) emphasized that it is essential that managers and staff maintain or update a website without having to go through a web designer. 


\section{METHODOLOGY}

\subsection{Case Study}

The service industry offers services as its main product rather than tangible objects. Such services are often not seen, smelled, heard, tasted, or felt before purchase. The industry has been growing steadily since the mid-20 ${ }^{\text {th }}$ century. In terms of GDP, service industries contributed three-fifths or more to most Asian countries such as Japan, Singapore, and Taiwan. It even exceeded half of the GDP of countries such as Thailand and South Korea. In the Philippines, the service industry contributed $52.9 \%$ to the 2004 GDP (Mitra, 2013). It kept on increasing until it reached $56.7 \%$ in 2014, and finally $58.8 \%$ in 2015 (Asia Pacific Economic Cooperation, 2015). Its impact on the Philippine economic growth imposes as to why the success of each service industry's marketing effort is relevant. Thus, having an effective online marketing strategy to use in these businesses becomes necessary as companies want to be found on the Internet, build a community, and position online. With the significance of online marketing strategy in the Philippines, identifying an effective strategy for the hospitality industry becomes a crucial task. This is to aid hospitality businesses to function efficiently in today's competitive environment. Consequently, the growth of these businesses in the country is essential to the broader social and economic development.

To identify an effective online marketing strategy, the goal of the decision problem must be defined. The goal of this study is to come up with priority online marketing strategies for the hospitality industry. Afterward, the analytical structure is established. The structure consists of the goal, perspective, criteria, and alternatives. It forms a decision-making model for online marketing strategies in light of two perspectives, namely business needs and customer needs. Addressing these two perspectives provides a comprehensive understanding of the possible tradeoffs between the two crucial interests where practitioners could operate their strategies in order to collectively achieve an effective online marketing strategy. From the perspective of customer needs, a set of criteria that emphasizes customer needs on an online marketing strategy is identified, and they consist of dependability (CC1), convenience (CC2), responsiveness (CC3), and credibility (CC4). On the other hand, on the perspective of satisfying business needs, the set of criteria highlights the needs of firms on what online marketing strategy to adopt, and these are cost (BC5), reach (BC6), customer loyalty (BC7), and convenience (BC8). These two sets of criteria are used to evaluate eight (8) alternatives (i.e., online marketing strategies) comprising Social Media (A1), Website (A2), Blogs (A3); E-mail Marketing (A4), Commerce community (A5), Online News (A6), Search engines (A7), and Pay-per-click (A8). Table 1 shows the decision criteria for the customer and business perspectives with their brief description, while Table 2 presents the online marketing strategies as decision alternatives.

\subsection{Analytic Hierarchy Process}

The AHP is a multi-criterion decision-making (MCDM) method developed by Saaty (1980), which decomposes a decision problem into a hierarchy of components (i.e., criteria, sub-criteria, alternatives). Decision-makers elicit pairwise comparisons of the elements in the same level with respect to an element in a higher immediate level using the Saaty fundamental 9-point scale (Saaty, 1980). Due to its computational tractability and scalability in dealing with large decision problems, the AHP is one of the most popular MCDM tools in the past two decades in areas of specific applications (e.g., Mardani et al., 2017). Some applications of the AHP were reported elsewhere, which include evaluating sustainable manufacturing initiatives (Ocampo \& Clark, 2015a; Ocampo \& Clark, 2015b), identifying critical indicators for sustainable manufacturing (Ocampo et al., 2015), computing a sustainable manufacturing index (Ocampo, 2015), and selecting criteria set for personnel selection (Castillo et al., 2017), among others. The computational process of the AHP involves the following steps: 
Table 1. Decision criteria

\begin{tabular}{|l|l|l|}
\hline \multicolumn{1}{|c|}{ Codes } & \multicolumn{1}{c|}{ Criteria } & \multicolumn{1}{|c|}{ Brief description } \\
\hline Customers' perspective & Dependability & $\begin{array}{l}\text { The technical aspect of the alternative such as accessibility, speed, the } \\
\text { safety of downloading files as well as providing up to date information }\end{array}$ \\
\hline CC1 & Convenience & $\begin{array}{l}\text { The ease of navigating through the standard menu and search engines for } \\
\text { its contents and directories. It also includes the user-friendliness of the } \\
\text { platform. }\end{array}$ \\
\hline CC3 & Responsiveness & It refers to answering questions promptly and giving feedback on time. \\
\hline CC4 & Credibility & $\begin{array}{l}\text { It refers to the trustworthiness, believability, and the ability to give } \\
\text { transparent information to customers. }\end{array}$ \\
\hline Businesses' perspective & Cost & Expenses for acquiring and maintaining an online strategy \\
\hline BC1 & Reach & Quantitative number of people that will be reached by the online strategy \\
\hline BC2 & Customer loyalty & Effectiveness of an online strategy in building customer relation \\
\hline BC3 & Convenience & Level of easiness in managing and developing the online strategy \\
\hline BC4 &
\end{tabular}

Table 2. Decision alternatives (i.e., online marketing strategies)

\begin{tabular}{|l|l|l|}
\hline \multicolumn{1}{|c|}{ Codes } & \multicolumn{1}{|c|}{ Alternatives } & \multicolumn{1}{c|}{ Brief description } \\
\hline A1 & Social media & Pages made on social networking sites \\
\hline A2 & Website & The site containing only significant information \\
\hline A3 & Blogs & Promotion of products through blogs \\
\hline A4 & Email Marketing & Email sent to a specific user \\
\hline A5 & Commerce community & Refers to the online shopping sites, among others \\
\hline A6 & Online news & Using news articles to promote products \\
\hline A7 & Search engine & Maximizing site visibility on search engines \\
\hline A8 & Pay-per-click & Ads paid by firms per click of the user \\
\hline
\end{tabular}

1. For each $k$ decision-maker, $k=1, \ldots, K$ construct a pairwise comparison matrix $A^{k}=\left(a_{i j}^{k}\right)_{n \times n}$, where $a_{i j}^{k}$ represents the relative importance of element (e.g., criterion) $i$ over element $j$ (i.e., $i$ and $j$ belong to the same level in the hierarchy) using the Saaty fundamental scale as shown in Table 3. Note that $a_{i j}^{k} \times a_{j i}^{k}=1$, which implies that by construction, $A^{k}$ is a positive reciprocal matrix.

2. Aggregate the individual judgments of $K$ decision-makers. The aggregate pairwise comparison matrix, denoted by $A=\left(a_{i j}\right)_{n \times n}$ is obtained using Equation (1):

$a_{i j}=\prod_{k=1}^{K}\left(a_{i j}^{k}\right)^{\beta_{k}}$ 
Table 3. Saaty fundamental scale

\begin{tabular}{|l|l|}
\hline \multicolumn{1}{|c|}{ Numerical rating scale } & \multicolumn{1}{c|}{ Verbal judgments } \\
\hline 1 & Equal importance \\
\hline 3 & Somewhat more important \\
\hline 5 & Much more important \\
\hline 7 & Very much more important \\
\hline 9 & Absolutely more important \\
\hline $2,4,6,8$ & Intermediate values \\
\hline
\end{tabular}

where $\beta_{k} \in[0,1] \cdot \sum_{k=1}^{K} \beta_{k}=1$ represents the relative importance of decision-maker $k$ on the decision problem. It may be described as a representation of a collection of knowledge and experience of the decision-maker on the problem domain. Similar to $A^{k}$, the aggregate matrix $A$ is also a positive reciprocal matrix.

3. Solve the characteristic equation shown in Equation (2). Saaty (1980) described that the estimate of the priorities of the elements $i=1, \ldots, n$ is obtained by solving the eigenvalue problem, and the priority vector is represented by the principal eigenvector generated from the maximum eigenvalue. Here:

$A \omega=\lambda_{\max } \omega$

where $\lambda_{\max } \in \mathbb{R}$ is the maximum eigenvalue and $\omega=\left(\omega_{1}, \ldots, \omega_{n}\right)$ becomes its corresponding eigenvector, which estimates the priorities of the $n$ elements.

4. Compute for the consistency index ( $C I)$ using Equation (3). In the AHP, $a_{i j}=\frac{\omega_{i}}{\omega_{j}}$, which implies that the aggregate judgment $a_{i j}$ estimates the ratio of the priorities of $i$ and $j$. It follows a transitive property, such that $a_{i j} \times a_{j k}=a_{i k}$. If $a_{i j} \times a_{j k} \neq a_{i k}$ for some $i, j$, and $k$, then inconsistent judgments exist. The AHP provides a mechanism in controlling the inconsistent judgments present in $A$ by computing for CI:

$C I=\frac{\left(\lambda_{\max }-n\right)}{n-1}$

5. Determine the consistency ratio ( $C R$ ) of $A$ through Equation (4):

$$
C R=\frac{C I}{R I}
$$


where $R I$ represents the random consistency indices for a given $n$, obtained by simulating thousands of pairwise comparison matrices of size $n \times n$. For $C R \leq 0.10$, the inconsistencies are acceptable; otherwise, decision-makers must repeat the elicitation of judgments in $A^{k}$ until $C R$ becomes acceptable.

6. Repeat steps 1 through 5 for the rest of the levels in the hierarchy. The global weight vectors are obtained using the multiplicative process of the AHP. See Saaty (1980) for the discussion.

\subsection{Technique for Order of Preference by Similarity to Ideal Solution}

As an MCDM method, the TOPSIS was developed by Chen and Hwang (1992) with reference to Hwang and Yoon (1981). Under this approach, the best alternative has the shortest distance from the positive ideal solution and the farthest distance from the negative ideal solution (Hwang \& Yoon, 1981). The positive ideal and the negative ideal solutions may not belong to the set of alternatives in the decision problem. Some applications in technology business incubation (Bacalan et al., 2019), lake eutrophication (Lin et al., 2020), and warehouse location (Ocampo et al., 2020) are reported recently in the literature. Reviews of the applications of the TOPSIS method were discussed by Behzadian et al. (2012), Shukla et al. (2017), and Yadav et al. (2018). The steps in implementing the TOPSIS method are the following:

1. Construct a decision matrix $X^{k}=\left(x_{i j}^{k}\right)_{m \times n}$, where $x_{i j}^{k}$ denotes the performance of $i$ th alternative to the $j$ th criterion perceived by the $k$ th decision-maker by a defined rating structure. For this work, Table 4 shows the rating structure.

2. Aggregate the decision matrices $X^{k}, \forall k=1, \ldots, K$. The aggregate decision matrix $X=\left(x_{i j}\right)_{m \times n}$ is obtained using Equation (5):

$x_{i j}=\frac{1}{K}\left(\sum_{k=1}^{K} x_{i j}^{k}\right), \forall i=1, \ldots, m, \forall j=1, \ldots, n$

3. Compute for the normalized decision matrix $R=\left(r_{i j}\right)_{m \times n}$ with Equation (6):

Table 4. The 10-point importance scale

\begin{tabular}{|l|l|}
\hline \multicolumn{1}{|c|}{ Criteria } & \multicolumn{1}{c|}{ Rating Scale } \\
\hline Customers' perspective & \\
\hline Dependability (CC1) & 10 (Very good) -1 (Very poor) \\
\hline Responsiveness (CC2) & 10 (Very good) -1 (Very poor) \\
\hline Credibility (CC3) & 10 (Very good) -1 (Very poor) \\
\hline Convenience (CC4) & 10 (Very good) -1 (Very poor) \\
\hline Businesses' perspective & \\
\hline Cost (BC1) & 10 (Very low) -1 (Very high) \\
\hline Reach (BC2) & 10 (Very high) -1 Very low) \\
\hline Customer Loyalty (BC3) & 10 (Very good) -1 (Very poor) \\
\hline Convenience (BC4) & 10 (Very good) -1 (Very poor) \\
\hline
\end{tabular}


$r_{i j}=\frac{x_{i j}}{\sqrt{\sum_{i=1}^{m} x_{i j}^{2}}}, \forall i=1, \ldots, m, \forall j=1, \ldots, n$

4. Obtain the weighted normalized decision matrix $V=\left(v_{i j}\right)_{m \times n}$. Equation (7) shows the required computation:

$v_{i j}=r_{i j} \times \omega_{j}, \forall i=1, \ldots, m, \forall j=1, \ldots, n$

$\omega_{j}$ represents the priority weight of criterion $j$ determined by any prioritization method.

5. Determine the positive ideal $\left(A^{+}\right)$and negative ideal $\left(A^{-}\right)$solutions:

$A^{+}=\left\{v_{1}^{+}, \ldots, v_{n}^{+}\right\}=\left\{\left(\max _{i} v_{i j} \mid j \in C_{b}\right),\left(\min _{i} v_{i j} \mid j \in C_{c}\right)\right\}$

$A^{-}=\left\{v_{1}^{-}, \ldots, v_{n}^{-}\right\}=\left\{\left(\min _{i} v_{i j} \mid j \in C_{b}\right),\left(\max _{i} v_{i j} \mid j \in C_{c}\right)\right\}$

$C_{b} \subseteq\{1, \ldots, n\}$ and $C_{c} \subseteq\{1, \ldots, n\}, C_{b} \cup C_{c}=\{1, \ldots, n\}$ are collections of maximizing (or benefit) and minimizing (or cost) criteria, respectively.

6. Calculate the separation measures $S_{i}^{+}$and $S_{i}^{-}, \forall i$, using Equation (10) and Equation (11), respectively:

$S_{i}^{+}=\sqrt{\sum_{j=1}^{n}\left(v_{i j}-v_{j}^{+}\right)^{2}}, \forall i=1, \ldots, m$

$S_{i}^{-}=\sqrt{\sum_{j=1}^{n}\left(v_{i j}-v_{j}^{-}\right)^{2}}, \forall i=1, \ldots, m$

7. Calculate the relative closeness of each alternative $i$ to the ideal solution, written as $R C_{i}$ which is defined as follows:

$R C_{i}=\frac{S_{i}^{-}}{S_{i}^{+}+S_{i}^{-}}, \forall i=1, \ldots, m$

8. Rank the preference order. The ranking of the alternatives is based on $R C_{i}$, arranged in decreasing order. 


\subsection{The Research Procedure}

First, questionnaires were distributed to ten respondents representing the hospitality industry: five experts from the business sectors and five customers. The first set of respondents are players in the different sectors under the hospitality industry. They were chosen based on their roles in the industry. The average age of these respondents is 29 years old. They consist of two marketing managers, one administrative supervisor, and two front desk officers. On the other hand, the second set of respondents are customers of the businesses under those relevant sectors. They have significant experience with online marketing strategies. The average age is 23 years old. Each set of respondents (i.e., businesses, customers) was asked to answer two sets of questionnaires. The first set was structured as a pairwise comparison matrix of criteria in accordance with the requirements of the AHP. It intends to answer the question: For each perspective, what are the priority weights of the criteria for evaluating online marketing strategies? These weights provide a basis for ranking the importance of the criteria in the identified set. The second set of questionnaire addresses the question: Which is the best online marketing strategy? To answer this question, the questionnaire was developed in such a way that a decision matrix is established for each decision-maker.

Secondly, the procedural steps of the AHP which are discussed in Section 3.2. were implemented to determine the weights of the criteria under each perspective. Third, with judgments generated from the second set of questionnaires, the TOPSIS method described in Equation (5) until Equation (12) was adopted to rank the alternatives (i.e., online marketing strategies) and consequently identify the best online marketing strategy. In the TOPSIS method, particularly in Equation (7), this work integrates the criteria weights obtained by the AHP. Next, the different online marketing strategies (i.e., alternatives) were ranked for each perspective using Equation (12). Thus, two different rankings were generated, one for each perspective. Consequently, for every online marketing strategy $i$, two $R C_{i}$ values were obtained along with the implementation of the TOPSIS method: $R C_{i}^{\text {customers }}$ and $R C_{i}^{\text {businesses }}$ for customers' and businesses' perspectives, respectively. Finally, online marketing strategy $i$ is mapped to the $\left(R C_{i}^{\text {customers }}, R C_{i}^{\text {businesses }}\right)$ space. This priority map provides a pictorial representation and mobility of the tradeoffs between the two perspectives when implementing a given online marketing strategy. The best online marketing strategy then maximizes the appetite and inclination of a decision-maker in the hospitality industry in relation to satisfying the interests of businesses and customers.

\section{RESULTS AND DISCUSSION}

The results of this work show the ranking of online strategies as a result of the customers' and businesses' perspectives in the hospitality industry. Structured as an MCDM problem, AHP is used to determine the priority weights of the criteria, and the evaluation of different alternatives (i.e., online marketing strategies) is carried out using TOPSIS. Table 5 presents the criteria weights, along with their ranks on the basis of these weights. These weights came from the customers' perspectives. With

Table 5. Criteria weights under customers' perspectives

\begin{tabular}{|l|l|l|}
\hline \multicolumn{1}{|c|}{ Criteria } & \multicolumn{1}{c|}{ Global priority weights } & \multicolumn{1}{c|}{ Rank } \\
\hline Dependability & 0.1008 & 4 \\
\hline Convenience & 0.1195 & 3 \\
\hline Responsiveness & 0.2111 & 2 \\
\hline Credibility & 0.5686 & 1 \\
\hline
\end{tabular}


the use of the AHP, the results show that credibility has the highest priority among the four criteria, followed by responsiveness, convenience, and dependability. On the other hand, Table 6 highlights the weights and priority ranking of the criteria under the businesses' perspectives. It reveals that customer loyalty has the highest priority, followed by reach, cost, and convenience.

After determining the weights of the different criteria under both perspectives, these weights are used to evaluate the online marketing strategies treated as alternatives. From the customers' perspectives in the hospitality industry, Table 7 presents the aggregate decision matrix using Equation (5). With Equation (6), its corresponding normalized decision matrix is generated, as shown in Table 8. Then, the weights of the criteria for customers' perspectives obtained from the AHP are integrated

Table 6. Criteria weights under businesses' perspectives

\begin{tabular}{|l|l|l|}
\hline \multicolumn{1}{|c|}{ Criteria } & \multicolumn{1}{c|}{ Global priority weights } & \multicolumn{1}{c|}{ Rank } \\
\hline Cost & 0.1203 & 3 \\
\hline Reach & 0.2411 & 2 \\
\hline Customer loyalty & 0.5434 & 1 \\
\hline Convenience & 0.0953 & 4 \\
\hline
\end{tabular}

Table 7. Aggregate decision matrix for the customer perspective

\begin{tabular}{|l|l|l|l|l|l|}
\hline \multicolumn{1}{|c|}{ Codes } & \multicolumn{1}{|c|}{ Alternatives } & Dependability & Convenience & Responsiveness & Credibility \\
\hline A1 & Social media & 7.6 & 8.8 & 8.2 & 6.2 \\
\hline A2 & Website & 9.2 & 7.4 & 6.8 & 8.8 \\
\hline A3 & Blogs & 7.2 & 8.2 & 7.0 & 8.4 \\
\hline A4 & Email marketing & 6.6 & 7.0 & 7.6 & 7.4 \\
\hline A5 & Commerce community & 6.6 & 7.6 & 7.2 & 6.8 \\
\hline A6 & Online news & 8.4 & 8.2 & 6.4 & 7.0 \\
\hline A7 & Search engines & 8.6 & 9.4 & 8.2 & 8.4 \\
\hline A8 & Pay-per-click & 7.2 & 7.4 & 7.2 & 7.2 \\
\hline
\end{tabular}

Table 8. Normalized decision matrix for the customer perspective

\begin{tabular}{|l|l|l|l|l|l|}
\hline \multicolumn{1}{|c|}{ Codes } & \multicolumn{1}{|c|}{ Alternatives } & Dependability & \multicolumn{1}{c|}{ Convenience } & Responsiveness & Credibility \\
\hline A1 & Social media & 0.34772 & 0.38719 & 0.39447 & 0.28944 \\
\hline A2 & Website & 0.42092 & 0.32559 & 0.32712 & 0.41082 \\
\hline A3 & Blogs & 0.32942 & 0.36079 & 0.33674 & 0.39215 \\
\hline A4 & Email marketing & 0.30197 & 0.30799 & 0.36560 & 0.34546 \\
\hline A5 & Commerce community & 0.30197 & 0.33439 & 0.34636 & 0.31745 \\
\hline A6 & Online news & 0.38432 & 0.36079 & 0.30788 & 0.32679 \\
\hline A7 & Search engines & 0.39347 & 0.41359 & 0.39447 & 0.39215 \\
\hline A8 & Pay-per-click & 0.32942 & 0.32559 & 0.34636 & 0.33613 \\
\hline
\end{tabular}


into Equation (7) in order to compute for the weighted normalized decision matrix. Table 9 shows the matrix $V$, along with vectors $A^{+}, A^{-}, S^{+}$, and $S^{-}$. With $S^{+}$and $S^{-}$as inputs to Equation (12), the $R C_{i}^{\text {customers }}$ values and the corresponding ranks of the online marketing strategies are presented in Table 10. It reveals that search engines (A7) emerge on top of the priority of the customers. The complete ranking is as follows:

$$
A 7 \succ A 2 \succ A 3 \succ A 4 \succ A 8 \succ A 6 \succ A 5 \succ A 1
$$

Social media stands at the bottom of the priority list.

Similarly, for the businesses' perspectives, Table 11 shows the aggregate decision matrix, Table 12 for the normalized decision matrix, Table 13 for the weighted normalized decision matrix and the relevant vectors obtained from Equation (8), Equation (9), Equation (10), and Equation (11), and

Table 9. Weighted normalized decision matrix for the customer perspective

\begin{tabular}{|l|l|l|l|l|l|l|l|}
\hline \multicolumn{1}{|c|}{ Codes } & \multicolumn{1}{|c|}{ Alternatives } & \multicolumn{1}{c|}{ Dependability } & Convenience & Responsiveness & Credibility & $S^{+}$ & $S^{-}$ \\
\hline A1 & Social media & 0.035 & 0.046 & 0.083 & 0.165 & 0.069 & 0.021 \\
\hline A2 & Website & 0.042 & 0.039 & 0.069 & 0.234 & 0.018 & 0.070 \\
\hline A3 & Blogs & 0.033 & 0.043 & 0.071 & 0.223 & 0.020 & 0.059 \\
\hline A4 & Email marketing & 0.030 & 0.037 & 0.077 & 0.196 & 0.041 & 0.034 \\
\hline A5 & Commerce community & 0.030 & 0.040 & 0.073 & 0.181 & 0.056 & 0.018 \\
\hline A6 & Online news & 0.039 & 0.043 & 0.065 & 0.186 & 0.052 & 0.024 \\
\hline A7 & Search engines & 0.040 & 0.049 & 0.083 & 0.223 & 0.011 & 0.063 \\
\hline A8 & Pay-per-click & 0.033 & 0.039 & 0.073 & 0.191 & 0.046 & 0.028 \\
\hline & $A^{+}$ & & & & & & \\
\hline & $A^{-}$ & 0.042 & 0.049 & 0.083 & 0.234 & & \\
\hline
\end{tabular}

Table 10. Relative closeness coefficients of different online marketing strategies (customers' perspectives)

\begin{tabular}{|l|l|l|l|}
\hline \multicolumn{1}{|c|}{ Codes } & \multicolumn{1}{|c|}{ Alternatives } & $R C_{i}^{\text {customers }}$ & \multicolumn{1}{c|}{ Rank } \\
\hline A1 & Social media & 0.23289 & 8 \\
\hline A2 & Website & 0.79878 & 2 \\
\hline A3 & Blogs & 0.75053 & 3 \\
\hline A4 & Email marketing & 0.45117 & 4 \\
\hline A5 & Commerce community & 0.24427 & 7 \\
\hline A6 & Online news & 0.31403 & 6 \\
\hline A7 & Search engines & 0.85198 & 1 \\
\hline A8 & Pay-per-click & 0.37893 & 5 \\
\hline
\end{tabular}


Table 11. Aggregate decision matrix for the business perspective

\begin{tabular}{|l|l|l|l|l|l|}
\hline \multicolumn{1}{|c|}{ Codes } & \multicolumn{1}{|c|}{ Alternatives } & \multicolumn{1}{c|}{ Cost } & \multicolumn{1}{c|}{ Reach } & \multicolumn{1}{c|}{$\begin{array}{c}\text { Customer } \\
\text { loyalty }\end{array}$} & \multicolumn{1}{c|}{ Convenience } \\
\hline A1 & Social media & 3.8 & 9.2 & 8.0 & 9.0 \\
\hline A2 & Website & 7.0 & 8.0 & 7.6 & 8.6 \\
\hline A3 & Blogs & 6.2 & 7.4 & 7.8 & 8.2 \\
\hline A4 & Email marketing & 5.6 & 7.4 & 7.4 & 7.6 \\
\hline A5 & Commerce community & 6.2 & 7.2 & 7.0 & 7.0 \\
\hline A6 & Online news & 6.6 & 8.4 & 7.8 & 8.6 \\
\hline A7 & Search engines & 7.8 & 8.8 & 7.6 & 8.2 \\
\hline A8 & Pay-per-click & 8.0 & 6.6 & 6.4 & 5.6 \\
\hline
\end{tabular}

Table 12. Normalized decision matrix for the business perspective

\begin{tabular}{|l|l|l|l|l|l|}
\hline \multicolumn{1}{|c|}{ Codes } & \multicolumn{1}{|c|}{ Alternatives } & \multicolumn{1}{c|}{ Cost } & \multicolumn{1}{c|}{ Reach } & \multicolumn{1}{c|}{$\begin{array}{c}\text { Customer } \\
\text { loyalty }\end{array}$} & \multicolumn{1}{c|}{ Convenience } \\
\hline A1 & Social media & 0.206 & 0.411 & 0.379 & 0.402 \\
\hline A2 & Website & 0.380 & 0.357 & 0.360 & 0.384 \\
\hline A3 & Blogs & 0.336 & 0.330 & 0.369 & 0.366 \\
\hline A4 & Email marketing & 0.304 & 0.330 & 0.350 & 0.339 \\
\hline A5 & Commerce community & 0.336 & 0.321 & 0.331 & 0.313 \\
\hline A6 & Online news & 0.358 & 0.375 & 0.369 & 0.384 \\
\hline A7 & Search engines & 0.423 & 0.393 & 0.360 & 0.366 \\
\hline A8 & Pay-per-click & 0.434 & 0.295 & 0.303 & 0.250 \\
\hline
\end{tabular}

Table 14 for $R C_{i}^{\text {businesses }}$ values. Consistent with the finding obtained from the customers' perspectives, Table 14 yields that search engines are the best online marketing strategy for businesses. The ranking becomes:

$A 7 \succ A 6 \succ A 2 \succ A 1 \succ A 3 \succ A 4 \succ A 5 \succ A 8$

With the $R C_{i}^{\text {customers }}$ and $R C_{i}^{\text {businesses }}$ values from Table 10 and Table 14, respectively, each online marketing strategy $i$ is mapped to the $\left(R C_{i}^{\text {customers }}, R C_{i}^{\text {businesses }}\right)$ space. This mapping, termed a priority tradeoff map, is shown in Figure 1. A7 (search engines) emerges as the online marketing strategy that maximizes both perspectives. It is also illustrated in Figure 1 that A2 (website) and A3 (blogs) apparently follow A7. However, selecting A2 and A3 implies some slight tradeoffs since A6 (online news) satisfies the businesses' perspectives more than A2 and A3. If the decision-makers appetite absorbs this slight preference, then the order $A 7 \succ A 2 \succ A 3$ represents the preferences of both perspectives in the hospitality industry. It can also be argued that Figure 1 places $A 5$ on the bottom of the priority list. While it has a slightly higher priority than $A 8$ in the businesses' perspectives, its position in the customers' perspectives is significantly lower than $A 8$. 
Table 13. Weighted normalized decision matrix for the business perspective

\begin{tabular}{|c|c|c|c|c|c|c|c|}
\hline Codes & Alternatives & Cost & Reach & $\begin{array}{c}\text { Customer } \\
\text { loyalty }\end{array}$ & Convenience & $S^{+}$ & $S^{-}$ \\
\hline A1 & Social media & 0.025 & 0.099 & 0.206 & 0.038 & 0.027 & 0.052 \\
\hline $\mathrm{A} 2$ & Website & 0.046 & 0.086 & 0.196 & 0.037 & 0.018 & 0.042 \\
\hline A3 & $\mathrm{B} \log \mathrm{s}$ & 0.040 & 0.080 & 0.201 & 0.035 & 0.023 & 0.042 \\
\hline A4 & Email marketing & 0.037 & 0.080 & 0.190 & 0.032 & 0.030 & 0.031 \\
\hline A5 & Commerce community & 0.040 & 0.078 & 0.180 & 0.030 & 0.037 & 0.024 \\
\hline A6 & Online news & 0.043 & 0.090 & 0.201 & 0.037 & 0.014 & 0.047 \\
\hline A7 & Search engines & 0.051 & 0.095 & 0.196 & 0.035 & 0.012 & 0.048 \\
\hline \multirow[t]{3}{*}{ A8 } & Pay-per-click & 0.052 & 0.071 & 0.165 & 0.024 & 0.052 & 0.027 \\
\hline & $A^{+}$ & 0.052 & 0.099 & 0.206 & 0.038 & & \\
\hline & $A^{-}$ & 0.025 & 0.071 & 0.165 & 0.024 & & \\
\hline
\end{tabular}

Table 14. Relative closeness coefficients of different online marketing strategies (businesses' perspectives)

\begin{tabular}{|l|l|l|l|}
\hline \multicolumn{1}{|c|}{ Codes } & \multicolumn{1}{c|}{ Alternatives } & $R C_{i}^{\text {businesses }}$ & Rank \\
\hline A1 & Social media & 0.65425 & 4 \\
\hline A2 & Website & 0.70277 & 3 \\
\hline A3 & Blogs & 0.63978 & 5 \\
\hline A4 & Email marketing & 0.50709 & 6 \\
\hline A5 & Commerce community & 0.39314 & 7 \\
\hline A6 & Online news & 0.77308 & 2 \\
\hline A7 & Search engines & 0.80398 & 1 \\
\hline A8 & Pay-per-click & 0.34575 & 8 \\
\hline
\end{tabular}

The results of this work identify the best online marketing strategy for the hospitality industry. It considers the perspectives of both customers and the businesses in which the search engine yields as the best online marketing strategy for both perspectives. As most customers practice nowadays, they go directly to search engines (e.g., Google) to look for hotels according to their set of preferences. Such a finding presents an opportunity for businesses in the hospitality industry, such as hotels and inns, to invest in maximizing the use of search engines. From the customers' perspectives, this strategy addresses aspects of credibility and responsiveness better, while it maximizes customer loyalty and reach for the businesses. The management of hospitality businesses should increase their visibility on search engines such as Google, Bing, and Yahoo, considering the number of competitors in the industry and competitors in the online platform. They could subscribe to such a strategy by investing in search engine optimization that would increase their business ranking in search engines, enabling their business to appear on the first page of every search. The priority tradeoff map provides an overview 


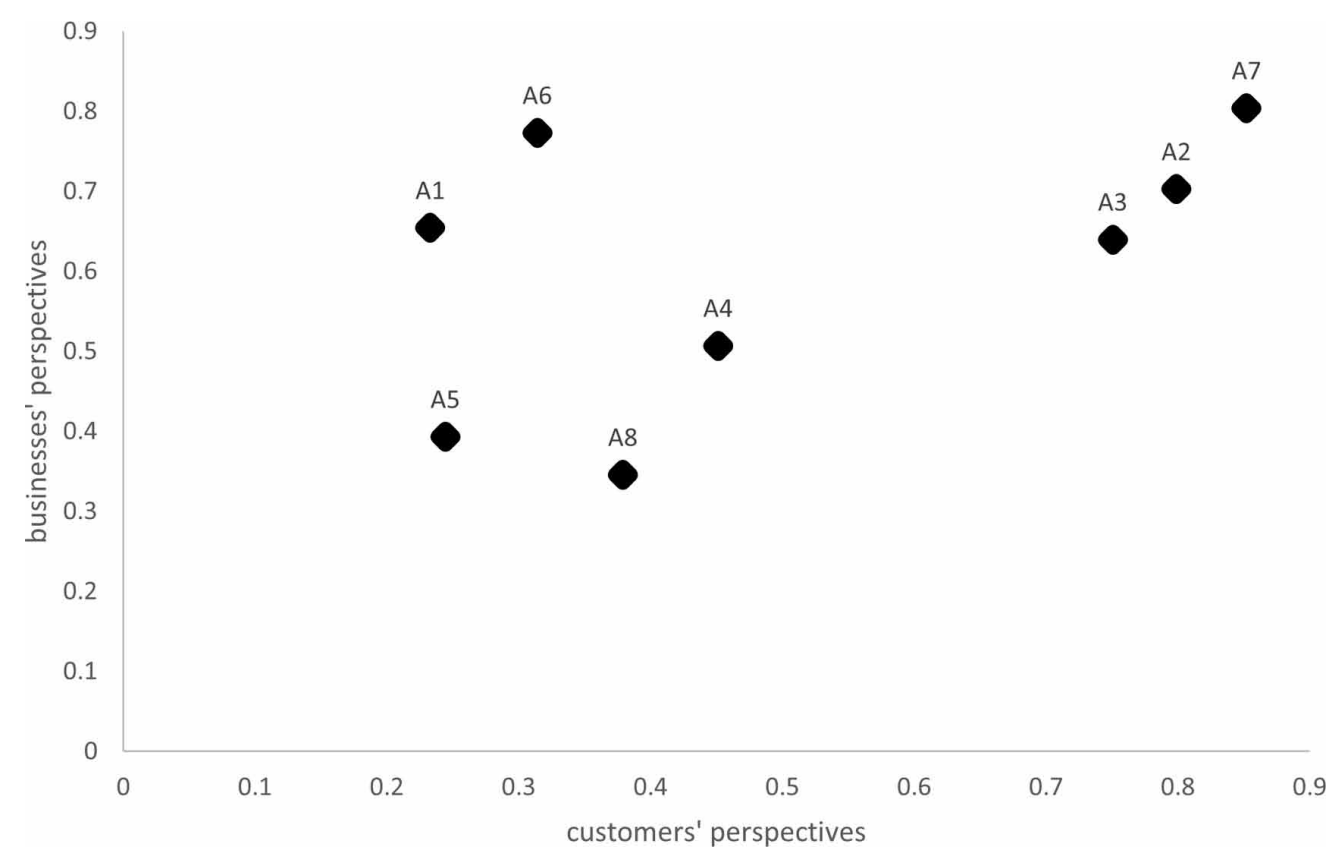

that search engines alone as an online marketing strategy could be implemented to maximize both perspectives. However, suppose the costs associated with increasing the business visibility in search engines are beyond the business's capacity to invest in. In that case, decision-makers could consider the use of company websites or blogs as online marketing strategies. Aside from these insights, the findings of this work, particularly of the ranking of the strategies in the priority tradeoff map, provide dependable support for resource allocation decisions.

\section{CONCLUSION AND FUTURE WORKS}

With an increased interest in online marketing, the hospitality industry is at the forefront of adopting such a platform to disseminate the value proposition of products and services. Crucial to adopting online marketing is identifying the most suitable strategies for strategic planning and efficient resource allocation decisions. However, without a comprehensive analytical approach that addresses the multi-criteria and multi-stakeholder environment of the decision-making process, identifying these strategies may yield counterintuitive results. Thus, this work offers a holistic evaluation platform that views the strategy selection problem in a multi-criteria scenario and provides a mechanism that handles a tradeoff approach for two seemingly interdependent perspectives, i.e., customers and businesses. To carry out such a platform, an integrated AHP-TOPSIS approach is proposed. The AHP considers the multiple criteria relevant in the evaluation process and identifies the priority criteria for both perspectives. Results show that the credibility of what an online marketing strategy offers seems to be the highest priority for the customers. This may imply that, in the absence of a more personal experience, customers are concerned about the trustworthiness of the information about the products or services elucidated through the online marketing platforms. On the other hand, businesses are putting more emphasis on how a strategy may enhance customer loyalty. Such a finding may be associated to repeat purchase as a precursor of a long-term customer relationship. These results are integrated into the TOPSIS method, which ranks the priority of online marketing strategies. 
Findings show that both perspectives prefer search engines as effective online marketing tools for the hospitality industry. Illustrating the results of TOPSIS as a priority tradeoff map of customers' and businesses' perspectives, findings yield that search engines, websites, and blogs are the most viable online marketing strategies that would address the multi-criteria and multi-stakeholder nature of the strategy selection problem. Decision-makers in the hospitality industry must position their initiatives and resources to develop the necessary support and infrastructure to plan and implement these priority online marketing strategies.

Nevertheless, the findings of this work must be treated with limitations. First, considering the Philippine context, the results of this work may reflect well to countries with similar demographic, cultural, and political profile but may not reflect well to others. Thus, a comparative analysis with other demographic locations may be future work. Secondly, the results reflect the insights of the decision-makers in the hospitality industry, and exploring other sectors in the service industry (e.g., tourism, food) would be an insightful work. Third, the limited number of respondents sets a stage for future work that could handle a significant number of stakeholders and decision-makers. Finally, the elicitation of judgments has an inherent ambiguity and imprecision, and the use of fuzzy set theory could augment such conditions. Integrating fuzzy sets into the hybrid AHP-TOPSIS is widely explored in the domain literature (e.g., Ocampo, 2019). 


\section{REFERENCES}

Abrate, G., Fraquelli, G., \& Viglia, G. (2012). Dynamic pricing strategies: Evidence from European hotels. International Journal of Hospitality Management, 31(1), 160-168. doi:10.1016/j.ijhm.2011.06.003

Ahmad, N. S., Musa, R., \& Harun, M. H. M. (2016). The impact of social media content marketing (SMCM) towards brand health. Procedia Economics and Finance, 37(16), 331-336. doi:10.1016/S2212-5671(16)30133-2

Ahn, H., Choi, E., \& Han, I. (2007). Extracting underlying meaningful features and canceling noise using independent component analysis for direct marketing. Expert Systems with Applications, 33(1), 181-191. doi:10.1016/j.eswa.2006.04.016

Akincilar, A., \& Dagdeviren, M. (2014). A hybrid multi-criteria decision making model to evaluate hotel websites. International Journal of Hospitality Management, 36, 263-271. doi:10.1016/j.ijhm.2013.10.002

Ambler, T., Bhattacharya, C. B., Edell, J., Keller, K. L., Lemon, K. N., \& Mittal, V. (2002). Relating brandand customer perspectives on marketing management. Journal of Service Research, 5(1), 13-25. doi:10.1177/1094670502005001003

Anupam, V., Freire, J., Kumar, B., \& Lieuwen, D. (2000). Automating Web navigation with the WebVCR. Computer Networks, 33(1-6), 503-517. doi:10.1016/S1389-1286(00)00073-6

Asia Pacific Economic Cooperation. (2015). The Philippines services sector and APEC. Asia Pacific Economic Cooperation.

Bacalan, R., Cupin, M., Go, L. A., Manuel, M., Ocampo, L., Kharat, M. G., \& Promentilla, M. A. (2019). The incubatees' perspective on identifying priority enabling factors for technology business incubators. Engineering Management Journal, 31(3), 177-192. doi:10.1080/10429247.2018.1540225

Behzadian, M., Otaghsara, S. K., Yazdani, M., \& Ignatius, J. (2012). A state-of the-art survey of TOPSIS applications. Expert Systems with Applications, 39(17), 13051-13069. doi:10.1016/j.eswa.2012.05.056

Belanche, D., Casaló, L. V., \& Guinalíu, M. (2012). Website usability, consumer satisfaction and the intention to use a website: The moderating effect of perceived risk. Journal of Retailing and Consumer Services, 19(1), 124-132. doi:10.1016/j.jretconser.2011.11.001

Benslimane, Y., \& Yang, Z. (2007). Linking commercial website functions to perceived usefulness: A free disposal hull approach. Mathematical and Computer Modelling, 46(9-10), 1191-1202. doi:10.1016/j.mcm.2006.12.008

Berman, R., \& Katona, Z. (2013). The role of search engine optimization in search marketing. Marketing Science, 32(4), 644-651. doi:10.1287/mksc.2013.0783

Bredzel-Skowera, K., \& Turek, T. (2015). The prospects of E-commerce in Poland. Procedia Computer Science, 65, 1114-1123. doi:10.1016/j.procs.2015.09.038

Brock, B., Carlson, S. C., Moilanen, M., \& Schillo, B. A. (2016). Reaching consumers: How the tobacco industry uses email marketing. Preventive Medicine Reports, 4, 103-106. doi:10.1016/j.pmedr.2016.05.020 PMID:27413669

Castillo, C. N., Degamo, F. K., Gitgano, F. T., Loo, L. A., Pacaanas, S. M., Toroy, N., Ocampo, L., Sia, L., \& Ocampo, C. O. (2017). Appropriate criteria set for personnel promotion across organizational levels using analytic hierarchy process (AHP). International Journal of Production Management and Engineering, 5(1), 11-22. doi:10.4995/ijpme.2017.5857

Chen, S. J., \& Hwang, C. L. (1992). Fuzzy multiple attribute decision making. Lecture notes in economics and mathematical system series (Vol. 375). Springer-Verlag. doi:10.1007/978-3-642-46768-4

Ducheneaut, N., \& Watts, L. A. (2005). In search of coherence: A review of e-mail research. Human-Computer Interaction, 20(1-2), 11-48. doi:10.1207/s15327051hci2001\&2_2

Ellis-Chadwick, F., \& Doherty, N. F. (2012). Web advertising: The role of e-mail marketing. Journal of Business Research, 65(6), 843-848. doi:10.1016/j.jbusres.2011.01.005 
Escobar-Rodríguez, T., \& Carvajal-Trujillo, E. (2013). An evaluation of Spanish hotel websites: Informational vs. relational strategies. International Journal of Hospitality Management, 33, 228-239. doi:10.1016/j. ijhm.2012.08.008

Figallo, C., \& Rhine, N. (2002). Building the knowledge management network: Best practices, tools, and techniques for putting conversation to work. John Wiley \& Sons.

Gan, L., Sim, C. J., Tan, H. L., \& Tna, J. (2007). Online relationship marketing by Singapore hotel websites. Journal of Travel \& Tourism Marketing, 20(3-4), 1-19. doi:10.1300/J073v20n03_01

Gardner, S. (2005). Buzz marketing with blogs for dummies. John Wiley \& Sons.

Garretson, C. (2007). The summer of spam: record growth, record irritation. Network World, 8, 16. Accessed from: https://www.pcworld.com/article/136061/article.html

Go, E., You, K. H., Jung, E., \& Shim, H. (2016). Why do we use different types of websites and assign them different levels of credibility? Structural relations among users' motives, types of websites, information credibility, and trust in the press. Computers in Human Behavior, 54, 231-239. doi:10.1016/j.chb.2015.07.046

Gretzel, U., Yuan, Y. L., \& Fesenmaier, D. R. (2000). Preparing for the new economy: Advertising strategies and change in destination marketing organizations. Journal of Travel Research, 39(2), 146-156. doi:10.1177/004728750003900204

Grunert, K. G. (1996). Automatic and strategic processes in advertising effects. Journal of Marketing, 60(4), 88-101. doi:10.1177/002224299606000408

Guo, X., Ling, L., Yang, C., Li, Z., \& Liang, L. (2013). Optimal pricing strategy based on market segmentation for service products using online reservation systems: An application to hotel rooms. International Journal of Hospitality Management, 35, 274-281. doi:10.1016/j.ijhm.2013.07.001

Halvorsen, K., Hoffmann, J., Coste-Manière, I., \& Stankeviciute, R. (2013). Can fashion blogs function as a marketing tool to influence consumer behavior? Evidence from Norway. Journal of Global Fashion Marketing, 4(3), 211-224. doi:10.1080/20932685.2013.790707

Han, J. H., \& Mills, J. E. (2006). Zero acquaintance benchmarking at travel destination websites: What is the first impression that national tourism organizations try to make? International Journal of Tourism Research, 8(6), 405-430. doi:10.1002/jtr.581

Hernández-Murillo, R., \& Martinek, C. J. (2009, April). Corporate social responsibility can be profitable. The Regional Economist, 4-5.

Ho, C. I., \& Lee, Y. L. (2007). The development of an e-travel service quality scale. Tourism Management, 28(6), 1434-1449. doi:10.1016/j.tourman.2006.12.002

Ho, W., \& Ma, X. (2018). The state-of-the-art integrations and applications of the analytic hierarchy process. European Journal of Operational Research, 267(2), 399-414. doi:10.1016/j.ejor.2017.09.007

Hung, W. H., Chang, L. M., Lin, C. P., \& Hsiao, C. H. (2014). E-readiness of website acceptance and implementation in SMEs. Computers in Human Behavior, 40, 44-55. doi:10.1016/j.chb.2014.07.046

Hwang, C. L., \& Yoon, K. (1981). Multiple attribute decision making: Methods and applications. Springer. doi:10.1007/978-3-642-48318-9

Ismail, F., Hashim, N. H., Schegg, R., \& Murphy, J. (2009). Internet Implementation Leapfrogging and Website Performance. In D. Tojib (Ed.), ANZMAC Sustainable Management and Marketing Conference (Vol. 1, pp. 1-10). Promaco Conventions Pty. Ltd.

Jelonek, D., \& Stępniak, C. (2014). Identification of e-customers' activities in the context of creating strategy, management and managers facing challenges of the $21^{\text {st }}$ century. Theoretical Background and Practical Applications, 295.

Jun, M., Yang, Z., \& Kim, D. (2004). Customers' perceptions of online retailing service quality and their satisfaction. International Journal of Quality \& Reliability Management, 21(8), 817-840. doi:10.1108/02656710410551728 
Kaplan, A. M., \& Haenlein, M. (2011). The early bird catches the news: Nine things you should know about micro-blogging. Business Horizons, 54(2), 105-113. doi:10.1016/j.bushor.2010.09.004

Karimkhani, C., Connett, J., Boyers, L., Quest, T., \& Dellavalle, R. P. (2014). Dermatology on instagram. Dermatology Online Journal, 20(7).

Kim, A. J., \& Ko, E. (2012). Do social media marketing activities enhance customer equity? An empirical study of luxury fashion brand. Journal of Business Research, 65(10), 1480-1486. doi:10.1016/j.jbusres.2011.10.014

Kirca, A. H., Jayachandran, S., \& Bearden, W. O. (2005). Market orientation: A meta-analytic review and assessment of its antecedents and impact on performance. Journal of Marketing, 69(2), 24-41. doi:10.1509/ jmkg.69.2.24.60761

Kotler, P. (2003). Marketing management (11th ed.). Pearson Education.

Ladany, S. P. (1996). Optimal market segmentation of hotel rooms-The non-linear case. Omega, 24(1), 29-36. doi:10.1016/0305-0483(95)00045-3

Latiff, Z. A., \& Safiee, N. A. S. (2015). New business set up for branding strategies on social media-Instagram. Procedia Computer Science, 72, 13-23. doi:10.1016/j.procs.2015.12.100

Lee, Y., \& Kozar, K. A. (2006). Investigating the effect of website quality on e-business success: An analytic hierarchy process (AHP) approach. Decision Support Systems, 42(3), 1383-1401. doi:10.1016/j.dss.2005.11.005

Lee, Y., \& Kozar, K. A. (2012). Understanding of website usability: Specifying and measuring constructs and their relationships. Decision Support Systems, 52(2), 450-463. doi:10.1016/j.dss.2011.10.004

Li, F., \& Du, T. C. (2011). Who is talking? An ontology-based opinion leader identification framework for word-of-mouth marketing in online social blogs. Decision Support Systems, 51(1), 190-197. doi:10.1016/j. dss.2010.12.007

Li, X., Wang, Y., \& Yu, Y. (2015). Present and future hotel website marketing activities: Change propensity analysis. International Journal of Hospitality Management, 47, 131-139. doi:10.1016/j.jjhm.2015.02.007

Lin, S. S., Shen, S. L., Zhou, A., \& Xu, Y. S. (2020). Approach based on TOPSIS and Monte Carlo simulation methods to evaluate lake eutrophication levels. Water Research, 187, 116437. doi:10.1016/j.watres.2020.116437 PMID:33002773

Linton, I. (2016). Taking technology to the market: A guide to the critical success factors in marketing technology. Routledge. doi:10.4324/9781315611785

Lituchy, T. R., \& Barra, R. A. (2008). International issues of the design and usage of websites for e-commerce: Hotel and airline examples. Journal of Engineering and Technology Management, 25(1-2), 93-111. doi:10.1016/j. jengtecman.2008.01.004

Liu, Q., Zhou, M., \& Zhao, X. (2015). Understanding News 2.0: A framework for explaining the number of comments from readers on online news. Information \& Management, 52(7), 764-776. doi:10.1016/j. im.2015.01.002

Lorenzo-Romero, C., Constantinides, E., \& Brünink, L. A. (2014). Co-creation: Customer integration in social media based product and service development. Procedia: Social and Behavioral Sciences, 148, 383-396. doi:10.1016/j.sbspro.2014.07.057

Madu, C. N., \& Madu, A. A. (2002). Dimensions of e-quality. International Journal of Quality \& Reliability Management, 19(3), 246-258. doi:10.1108/02656710210415668

Mano, R. S., \& Mesch, G. S. (2010). E-mail characteristics, work performance and distress. Computers in Human Behavior, 26(1), 61-69. doi:10.1016/j.chb.2009.08.005

Mardani, A., Zavadskas, E. K., Khalifah, Z., Zakuan, N., Jusoh, A., Nor, K. M., \& Khoshnoudi, M. (2017). A review of multi-criteria decision-making applications to solve energy management problems: Two decades from 1995 to 2015. Renewable \& Sustainable Energy Reviews, 71, 216-256. doi:10.1016/j.rser.2016.12.053

McGlaughlin, F., Doyle, J., \& Bortone, B. (2012). Key industry trends for generating leads of the highest quality. 2012 Lead Generation Benchmark Report. 
McGuigan, J. R., Moyer, R. C., \& Harris, F. H. D. (2013). Managerial economics: applications, strategies and tactics. Nelson Education.

McKee, E. (2016). Dwelling in conflict: Negev landscapes and the boundaries of belonging. Stanford University Press. doi:10.1515/9780804798327

Mills, A. J., \& Plangger, K. (2015). Social media strategy for online service brands. Service Industries Journal, 35(10), 521-536. doi:10.1080/02642069.2015.1043277

Mitra, R. M. (2013). Leveraging service sector growth in the Philippines. Asian Development Bank Economics Working Paper Series, No. 366.

Moustakas, E., Ranganathan, C., \& Duquenoy, P. (2006). E-mail marketing at the crossroads: A stakeholder analysis of unsolicited commercial e-mail (spam). Internet Research, 16(1), 38-52. doi:10.1108/10662240610642532

Mustafi, S., Jost, L., \& Nguyen, T. (2011). The relationship between online and offline marketing. University of Applied Sciences Northwestern Switzerland. Accessed from: http://fjalaime.ch/wp-content/uploads/TheRelationship-between-Online-and-Offline-Marketing.pdf

Nazar, N. (2009). Exploring SEO techniques for Web 2.0 websites (Master's thesis). Chalmers University of Technology. Accessed from: https://odr.chalmers.se/bitstream/20.500.12380/96559/1/96559.pdf

Netmarketshare. (2013). Search engine market share. Accessed from: http://marketshare.hitslink. com/searchengine-market-share.aspx?spider1/41\&qprid1/44

Ocampo, L., \& Clark, E. (2015a). An analytic hierarchy process (AHP) approach in the selection of sustainable manufacturing initiatives: A case in a semiconductor manufacturing firm in the Philippines. International Journal of the Analytic Hierarchy Process, 7(1), 32-49. doi:10.13033/ijahp.v7i1.223

Ocampo, L., \& Clark, E. (2015b). A proposed framework in developing sustainable manufacturing initiatives using Analytic Hierarchy Process (AHP). Industrial and Systems Engineering Review, 3(1), 7-16.

Ocampo, L., Genimelo, G. J., Lariosa, J., Guinitaran, R., Borromeo, P. J., Aparente, M. E., Capin, T., \& Bongo, M. (2020). Warehouse location selection with TOPSIS group decision-making under different expert priority allocations. Engineering Management in Production and Services, 12(4), 22-39.

Ocampo, L. A. (2015). A hierarchical framework for index computation in sustainable manufacturing. Advances in Production Engineering \& Management, 10(1), 40-50. doi:10.14743/apem2015.1.191

Ocampo, L. A. (2019). Applying fuzzy AHP-TOPSIS technique in identifying the content strategy of sustainable manufacturing for food production. Environment, Development and Sustainability, 21(5), 2225-2251. doi:10.1007/ s10668-018-0129-8

Ocampo, L. A., Vergara, V. G. N., Impas, C. G., Tordillo, J. A. S., \& Pastoril, J. S. (2015). Identifying critical indicators in sustainable manufacturing using analytic hierarchy process (AHP). Manufacturing and Industrial Engineering, 14(3-4).

Olbrich, R., \& Schultz, C. (2008). Search engine marketing and click fraud. Research Paper No.5. Fern Universität, Hagen. Accessed from: http://www.fernuni-hagen.de/MARKETING/material/downloads/ no5_web.pdf

Ozturk, A. B., Nusair, K., Okumus, F., \& Hua, N. (2016). The role of utilitarian and hedonic values on users' continued usage intention in a mobile hotel booking environment. International Journal of Hospitality Management, 57, 106-115. doi:10.1016/j.ijhm.2016.06.007

Pan, B., MacLaurin, T., \& Crotts, J. C. (2007). Travel blogs and the implications for destination marketing. Journal of Travel Research, 46(1), 35-45. doi:10.1177/0047287507302378

Park, D., \& Shin, K. (2012). The service sector in Asia: is it an engine of growth? Asian Development Bank Economics Working Paper Series, No. 322, Asian Development Bank (ADB). http://hdl.handle.net/11540/1257

Pavlov, O. V., Melville, N., \& Plice, R. K. (2008). Toward a sustainable email marketing infrastructure. Journal of Business Research, 61(11), 1191-1199. doi:10.1016/j.jbusres.2007.11.010

Reichheld, F. F., \& Schefter, P. (2000). E-Loyalty: Your secret weapon on the web. Harvard Business Review, $78(4), 105-113$. 
Rosenberg, L. J., \& Czepiel, J. A. (1984). A marketing approach for customer retention. Journal of Consumer Marketing, 1(2), 45-51. doi:10.1108/eb008094

Rus, R. V., \& Negruşa, A. L. (2014). Online hotel booking systems in Romania. Procedia Economics and Finance, 15, 1235-1242. doi:10.1016/S2212-5671(14)00583-8

Saaty, T. L. (1980). The analytic hierarchy process. McGraw-Hill.

Schmidt, J. (2007). Blogging practices: An analytical framework. Journal of Computer-Mediated Communication, 12(4), 1409-1427. doi:10.1111/j.1083-6101.2007.00379.x

Shih, B. Y., Chen, C. Y., \& Chen, Z. S. (2013). Retracted: An empirical study of an internet marketing strategy for search engine optimization. Human Factors and Ergonomics in Manufacturing \& Service Industries, 23(6), 528-540. doi:10.1002/hfm.20348

Shukla, A., Agarwal, P., Rana, R. S., \& Purohit, R. (2017). Applications of TOPSIS algorithm on various manufacturing processes: A review. Materials Today: Proceedings, 4(4), 5320-5329. doi:10.1016/j. matpr.2017.05.042

Singh, N., \& Matsuo, H. (2004). Measuring cultural adaptation on the Web: A content analytic study of US and Japanese Web sites. Journal of Business Research, 57(8), 864-872. doi:10.1016/S0148-2963(02)00482-4

Slater, D. (2014). Content Marketing: Recycling \& Reuse: How your best online content can attract and engage new customers. i30 Media Corporation.

Slivar, I., \& Križman Pavlović, D. (2012). Internet marketing communication of tourist destinations: Review of DMO websites in Europe. Economic Research-Ekonomska Istraživanja, 2012(2), 173-186. doi:10.1080/13 31677X.2012.11517581

Smith, K. T. (2011). Digital marketing strategies that Millennials find appealing, motivating, or just annoying. Journal of Strategic Marketing, 19(6), 489-499. doi:10.1080/0965254X.2011.581383

Spais, G. S. (2010). Search Engine Optimization (SEO) as a dynamic online promotion technique: The implications of activity theory for promotion managers. Innovative Marketing, 6(1), 7-24.

Stuit, M., \& Wortmann, H. (2012). Discovery and analysis of e-mail-driven business processes. Information Systems, 37(2), 142-168. doi:10.1016/j.is.2011.09.008

Subramani, M. R., \& Rajagopalan, B. (2003). Knowledge-sharing and influence in online social networks via viral marketing. Communications of the ACM, 46(12), 300-307. doi:10.1145/953460.953514

Tamilarasan, R. (2014). E-Marketing - Is it indispensable for today's marketing? i-Manager's. Journal of Management, 9(1), 1-5.

Thelwall, M. (2001).Commercial web site links. Internet Research, 11(2), 114-124. doi:10.1108/10662240110388224

Turban, E., Leidner, D., McLean, E., Wetherbe, J., \& Cheung, C. (2006). Information technology for management: Transforming organizations in the digital economy (Vol. 5). Wiley.

Valos, M. J., Ewing, M. T., \& Powell, I. H. (2010). Practitioner prognostications on the future of online marketing. Journal of Marketing Management, 26(3-4), 361-376. doi:10.1080/02672571003594762

Velasquez, M., \& Hester, P. T. (2013). An analysis of multi-criteria decision making methods. International Journal of Operations Research, 10(2), 56-66.

Venkatraman, M. P. (1989). Opinion leaders, adopters, and communicative adopters: A role analysis. Psychology and Marketing, 6(1), 51-68. doi:10.1002/mar.4220060104

Wagner, N., Hassanein, K., \& Head, M. (2014). The impact of age on website usability. Computers in Human Behavior, 37, 270-282. doi:10.1016/j.chb.2014.05.003

Wuyts, S., Rindfleisch, A., \& Citrin, A. (2015). Outsourcing customer support: The role of provider customer focus. Journal of Operations Management, 35(1), 40-55. doi:10.1016/j.jom.2014.10.004

Yadav, S. K., Joseph, D., \& Jigeesh, N. (2018). A review on industrial applications of TOPSIS approach. International Journal of Services and Operations Management, 30(1), 23-28. doi:10.1504/IJSOM.2018.091438 
Yang, X., \& Wang, D. (2015). The exploration of social media marketing strategies of destination marketing organizations in China. Journal of China Tourism Research, 11(2), 166-185. doi:10.1080/19388160.2015.10 17071

Ye, Q., Law, R., Gu, B., \& Chen, W. (2011). The influence of user-generated content on traveler behavior: An empirical investigation on the effects of e-word-of-mouth to hotel online bookings. Computers in Human Behavior, 27(2), 634-639. doi:10.1016/j.chb.2010.04.014

Zeithaml, V. A. (2002). Service excellence in electronic channels. Managing Service Quality, 12(3), 135-139. doi:10.1108/09604520210429187

Lanndon Ocampo is an Associate Professor in the Department of Industrial Engineering at Cebu Technological University (Philippines). He received his Ph.D. in Industrial Engineering from De La Salle University (Philippines) and his MEng and BSc (cum laude) degrees in Industrial Engineering as well as MSc in Mathematics from the University of San Carlos (Philippines). He has authored over 100 international peer-reviewed journal papers and has presented papers at over 30 research conferences. His research interests include optimization, multi-attribute decision-making, decision science, systemic risk analysis, and sustainable manufacturing. He is a Member of the Editorial Board of the Advances in Production Engineering and Management, International Journal of Business and Systems Research (Inderscience), International Journal of Management and Decision Making (Inderscience), Engineering Management in Production and Services, and the Proceedings in Manufacturing Systems. He is a 2017 Outstanding Young Scientist awardee by the National Academy of Science and Technology, Philippines (NAST $P H)$, and a 2018 Outstanding Cebuano awardee in the field of Science and Technology. He is named one of 2018 THE ASIAN SCIENTIST 100 - an annual listing of the region's top researchers, academics, and innovators. Most recently, he is conferred as the 2019 Achievement Awardee of the National Research Council of the Philippines (NRCP) under the Division of Engineering and Industrial Research.

Kafferine Yamagishi is an Assistant Professor, and currently the Chair of the Department of Tourism Management, College of Management and Entrepreneurship at Cebu Technological University, Philippines. She attained her Master of Management major in Tourism Management at the University of San Carlos (Philippines), where she is currently taking up her Doctor of Philosophy degree in Business Administration. She received her Certification in Professional Education and attained her Master of Arts in Education major in Administration and Supervision at Cebu Technological University. She graduated Bachelor of Science in Tourism (cum laude) at the University of San Jose-Recoletos, Philippines. Before joining academia, she worked both in the hospitality and tourism industry. She currently has nine published articles in Scopus-indexed journals. Also, she has presented papers to research conferences throughout her academic career. Her research interests include tourism management, destination planning, tourism marketing, and events management. 